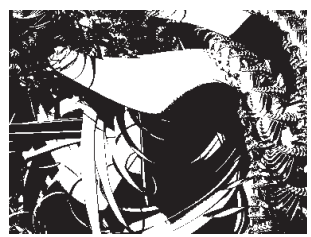

\title{
SELF-CAREER MANAGEMENT: INTERVENTION WITH RESEARCH GRANT HOLDERS
}

Joana Carneiro PINTO, Maria do Céu TAVEIRA

Psychology Research Center, University of Minho, Braga, Portugal

UDK: 65.013

Izvorni znanstveni rad

Primljeno: 23. 2. 2010.

This article reports the findings of the assessment of the effectiveness of a self-career management intervention, named "Self-Career Management Seminar", specifically developed for, and implemented in a group of research grant holders. The program invites participants to foster their self-knowledge, the knowledge about advanced training opportunities, employment creation and attainment, as well as, life-career planning and decision-making competencies. The intervention was applied in 80 research grant holders $(50,62.5 \%$ experimental group; 30 , $37.5 \%$ control group; $51,63.8 \%$ women; Mage $=28.94$, SDage $=5.83$ ), at a public university in the northwest of Portugal, who completed measures of career exploration, and of career concerns, at a pre and post-test. Results showed equivalence between experimental and control groups, at pre-treatment, in almost all assessed dimensions. Furthermore, in comparison with the control group, research grant holders who attended this intervention had, at post-test, higher levels of career exploration. This study intends to emphasize the need for the development of intervention programs tailored to specific population groups, such as the research grant holders.

Keywords: self-career management, intervention, effectiveness

$\triangle$ Joana Carneiro Pinto, Psychology Research Center, Campus of Gualtar, University of Minho, 4710-057 Braga, Portugal. E-mail: joanacpinto_@hotmail.com

In recent decades, both Vocational Psychology and Organizational Psychology have been dedicated to the study of the organizational scenario. Although different purposes directed that study, these two psychology branches seem unanimous in concluding that the world of work has been marked by a 
DRUŠ. ISTRAŽ. ZAGREB GOD. 20 (2011) BR. $3(113)$

STR. 793-812

PINTO, J. C., TAVEIRA, M. C SELF-CAREER. series of vast and profound changes. These dynamics have contributed, more or less directly, to the current business climate, guided by high levels of uncertainty and insecurity, and low control and predictability.

These constraints felt in the organizational world of the 21st century confront us with the need to rethink the traditional theories, techniques and concepts of career (Athanasou and Esbroeck, 2008; Savickas, 2008). The new careers, called in the literature "boundaryless career" (Arthur and Rousseau, 1996; DeFillipi and Arthur, 1994), "protean career" (Hall, 1996; Hall and Moss, 1998), "new career" (King, 2004), "portfolio career" (Handy, 1994) or even "intelligent career" (Arthur et al., 1995), are transitory, flexible and dynamic, and no longer transmit security nor stability, with multiple interruptions and direction changes (Van Vianen et al., 2008). Therefore, in order to respond to these new challenges of the world of work, career services providers have sought to develop new theoretical models that are clarified and representative of the new organizational realities. Examples of those attempts are the constructivist epistemologies (Savickas, 2005, 2008), and the narrative theories (Chen, 1997; Mcllveen and Patton, 2007).

The new career theories argue that people do not construct reality itself but multiple representations of reality (Savickas, 2005). Each of those realities belongs to the person who built it. Therefore, each life, each career, is a construction that reflects a subjective experience, built through a series of "interpretative and interpersonal processes" which allow individuals to assign "meaning and significance" to their behavior (Savickas, 2005, 42). The significance that is assigned is cultural, social, historical and linguistically determined. Therefore, it is possible to say that people are "meaning-makers", and each career is a history of authorship itself, in which it is intended to explain "how the self of yesterday became the self of today and will become the self of tomorrow" (Savickas, 2005, 58). In addition to this focus on career and self as a story that is being built at every moment, these new theories also clarify quite sharply that all people, men, women, students, or employees, are responsible for the construction of their own paths of life (Chen, 1997). Taking into consideration the quality of agency given to them, people should not be regarded as mere victims of the changes that occur in different social contexts. It is essential that people take an active role and become managers of their own life/career (Van Vianen et al., 2008).

Self-career management can be translated into a range of cognitive and behavioral strategies (Frayne and Geringer, 2000), developed by each individual, with the purpose of exercising control over their own career goals (Orpen, 1994). It can be defined as a continuous process of solving problems, through 
DRUŠ. ISTRAŽ. ZAGREB GOD. 20 (2011), BR. $3(113)$

STR. 793-812

PINTO, J. C. TAVEIRA, M. C. SELF-CAREER. which individuals develop a greater awareness about themselves and the world of work (gathering relevant information about their values, interests, skills, strengths and weaknesses, preferred lifestyle, occupations, jobs and business alternatives), identify realistic career goals based on this information, and implement and monitor career strategies that increase the likelihood of achieving these career objectives (e.g., Greenhaus and Callanan, 1994; Kossek et al., 1998; Noe, 1996). It is through career management that people can actively get involved in the construction of their "best possible future" (Savickas, 2008, 110). Although it is considered that an increasing number of people might be using this method in their career, this does not mean, however, that all people are, indeed, effective self-managers (Frayne and Geringer, 2000).

The attendance itself of a career intervention program (e.g., individual career guidance, group career guidance, career management seminars, informational meetings, printed materials, use of computer software or Internet) does not ensure the achievement of the participant's career goals. In this sense, different authors (e.g., Whiston and Buck, 2008) have questioned whether these career guidance programs are worth all the investments. And, despite the conclusions of the comprehensive literature reviews that career intervention is effective and produces positive changes in client's career development (Fretz, 1981; Holland et al., 1981; Rounds and Tinsley, 1984; Swanson, 1995), there are still many uncertainties about what works, with what kind of clients, and under what circumstances (Luzzo, 2000).

This question of what works with what kind of clients has assumed particular importance for some theorists (e.g., Fretz, 1981), which have stressed the need to develop career guidance and counseling interventions that are specific to different groups of population. Currently, people who seek career services are increasingly diverse (Luzzo, 2000), particularly in age, sex, race, socioeconomic and cultural terms. In addition to these characteristics, one aspect that inevitably cannot be neglected, relates to the different needs of support, which are experienced by different people, depending on their different career stages. From the moment that this diversity is recognized by career professionals, they have to assume the responsibility for developing career programs that are meeting these different needs. People tend to enroll themselves in services they believe that have been, specifically developed for them. In addition, a program effectiveness will depend on the concern, upon its development, in meeting the characteristics and needs of each client and/or specific group of clients (Whiston and Buck, 2008). 
DRUŠ. ISTRAŽ. ZAGREB GOD. 20 (2011) BR. $3(113)$

STR. 793-812

PINTO, J. C. TAVEIRA, M. C. SELF-CAREER..

\section{METHOD}

\section{Participants}

In this sense, taking into account the literature review that has been made, as well as, the challenge from Whiston and Buck (2008), to make assessments of programs specifically designed for, and with, specific groups of individuals, this paper reports the findings of a study designed to assess the results of the impact of the career self-management program, the "Self-Career Management Seminar", in the exploration process, and type of career concerns, of research grant holders.

Participants were organized in an experimental and a control group. The sample selection was based on a convenience sampling, which used the subjects that were available at the time of data collection, but also that met the following criteria: (a) frequency of a doctoral program or research project, (b) receipt of a scholarship, (c) voluntary participation in research, and (d) lack of simultaneous psychological counseling. Accordingly, this study involves 80 research grant holders $(50,62.5 \%$ experimental group; $30,37.5 \%$ control group) developing their research activities at a public university in the northwest of Portugal.

The experimental group included 50 subjects $(28,56 \%$ female; 22, 44\% male; Mage $=29.04 ; \mathrm{SDage}=5.48$ ) that voluntarily enrolled in a self-career management intervention, developed by professionals of the Career Guidance and Counseling Centre of the University of Minho. These researchers were developing their activities in Engineering $(n=29,58 \%)$, Psychology $(n=9,18 \%)$, Education $(n=5,10 \%)$, Biology $(3,6 \%)$, Math (1, 2\%), Law (1, 2\%), Media (1,2\%), and Sociology $(1,2 \%)$ domains. They were working, on average, about 63.18 months $(\mathrm{SD}=73.94$; $\mathrm{Min}=0$; $\mathrm{Max}=348)$, were on the actual company/university, on average, about 34.48 months $(\mathrm{SD}=38.87$; Min=0; Max=176), and were developing their current research positions, on average, about 20.10 months $(\mathrm{SD}=18.99$; Min $=0 ;$ Max =72). Eighteen researchers $(36 \%)$ would see their research contract concluded in less than a year.

The control group consisted of 30 subjects $(23,76.7 \%$ female; 7, 23.3\% male; Mage $=28.77 ; \mathrm{SDage}=6.47)$ who agreed to participate in this research by filling the evaluation instruments. These subjects were enrolled in Psychology $(25,83.3 \%)$, Education (2, 6.7\%), Engineering (1,3.3\%), Physics (1,3.3\%), and Management $(1,3.3 \%)$ research areas. Their mean time of work was 61.33 months $(\mathrm{SD}=78.84$; Min=5; Max=336), their mean time in the actual company was 35.40 months $(\mathrm{SD}=37.99$; Min=2; Max=144) and, their mean time in the actual position 
(1) TABLE 1

Socio-demographic data

was 21.93 months $(\mathrm{SD}=30.31$; Min=1; $\mathrm{Max}=144)$. Eight researchers $(26.7 \%)$ would see their research contract finished in less than a year.

Experimental and control groups were equivalent with respect to the assessed dimensions, excepting sex, main research area, and anticipation of a change in position (see Table 1).

\begin{tabular}{|c|c|c|c|c|c|c|c|c|c|c|c|c|}
\hline \multirow[t]{2}{*}{ Sample } & \multirow{2}{*}{ 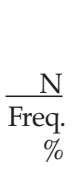 } & \multicolumn{2}{|r|}{ Sex } & \multirow[b]{2}{*}{$\begin{array}{r}\text { Mean } \\
\text { SD }\end{array}$} & \multirow{2}{*}{$\begin{array}{l}\text { Age } \\
\text { Min } \\
\text { Max }\end{array}$} & \multicolumn{2}{|c|}{$\begin{array}{r}\text { Work } \\
\text { mean time } \\
\end{array}$} & \multicolumn{2}{|c|}{$\begin{array}{r}\text { Company } \\
\text { mean time }\end{array}$} & \multicolumn{2}{|c|}{$\begin{array}{r}\text { Position } \\
\text { mean time }\end{array}$} & \multirow{2}{*}{$\begin{array}{r}\begin{array}{r}\text { Change } \\
\text { in } \\
\text { position }\end{array} \\
\text { Yes } \\
\%\end{array}$} \\
\hline & & $\begin{array}{l}\mathrm{F} \\
\%\end{array}$ & $\begin{array}{l}\mathrm{M} \\
\%\end{array}$ & & & $\begin{array}{r}\text { Mean } \\
\text { SD }\end{array}$ & $\begin{array}{l}\text { Min } \\
\text { Max }\end{array}$ & $\begin{array}{r}\text { Mean } \\
\text { SD }\end{array}$ & $\begin{array}{l}\text { Min } \\
\text { Max }\end{array}$ & $\begin{array}{r}\text { Mean } \\
\text { SD }\end{array}$ & $\begin{array}{l}\text { Min } \\
\text { Max }\end{array}$ & \\
\hline Total Sample & $\begin{array}{r}80 \\
100.0\end{array}$ & $\begin{array}{r}51 \\
63.8\end{array}$ & $\begin{array}{r}29 \\
36.2\end{array}$ & $\begin{array}{r}28.94 \\
5.83\end{array}$ & $\begin{array}{l}22 \\
48\end{array}$ & $\begin{array}{l}62.49 \\
75.33\end{array}$ & $\begin{array}{r}0 \\
348\end{array}$ & $\begin{array}{l}34.82 \\
38.30\end{array}$ & $\begin{array}{r}0 \\
176\end{array}$ & $\begin{array}{l}20.79 \\
23.70\end{array}$ & $\begin{array}{r}0 \\
144\end{array}$ & $\begin{array}{r}26 \\
32.5\end{array}$ \\
\hline Experimental Group & $\begin{array}{r}50 \\
62.5\end{array}$ & $\begin{array}{r}28 \\
56.0\end{array}$ & $\begin{array}{r}22 \\
44.0\end{array}$ & $\begin{array}{r}29.04 \\
5.48\end{array}$ & $\begin{array}{l}22 \\
46\end{array}$ & $\begin{array}{l}63.18 \\
73.94\end{array}$ & $\begin{array}{r}0 \\
348\end{array}$ & $\begin{array}{l}34.48 \\
38.87\end{array}$ & $\begin{array}{r}0 \\
176\end{array}$ & $\begin{array}{l}20.10 \\
18.99\end{array}$ & $\begin{array}{r}0 \\
72\end{array}$ & $\begin{array}{r}18 \\
36.0\end{array}$ \\
\hline Control Group & $\begin{array}{r}30 \\
37.5\end{array}$ & $\begin{array}{r}23 \\
76.7\end{array}$ & $\begin{array}{r}7 \\
23.3\end{array}$ & $\begin{array}{r}28.77 \\
6.47\end{array}$ & $\begin{array}{l}23 \\
48\end{array}$ & $\begin{array}{l}61.33 \\
78.84\end{array}$ & $\begin{array}{r}5 \\
336\end{array}$ & $\begin{array}{l}35.40 \\
37.99\end{array}$ & $\begin{array}{r}2 \\
144\end{array}$ & $\begin{array}{l}21.93 \\
30.31\end{array}$ & $\begin{array}{r}2 \\
144\end{array}$ & $\begin{array}{r}8 \\
26.7\end{array}$ \\
\hline
\end{tabular}

\section{Procedure}

The Self-Career Management Seminar (SCMS) has been developed specifically to facilitate the self-career management of research grant holders. Thus, this intervention program aims to foster individuals' knowledge about themselves and the world, the development of career goals, and the implementation of an action plan oriented to increase the probability of obtaining those goals, through the maintenance of a positive outlook about their future career. This program was developed based on a number of previous studies (e.g., Silva, 2008; Soares, 1998; Taveira et al., 2007), which evidenced the more common career intervention needs among graduation and post-graduation populations at the University of Minho. Specifically, these studies showed that students (a) are looking for assistance in the University career counseling services, alarmed by the constant news related to unemployment in higher education, (b) have a traditional interpretation of their career, as a vocation that they could express through a professional path in which they enter and must remain throughout their working lives, (c) need and want more support in managing their career roles, particularly, to cope with and surmount family-work role conflict; and (d) identify a lack of exploratory orientation, that is, they do not know how and where to explore the information they need to make their career decisions.

The SCMS, applied to the experimental group between January and June 2008, was structured into three main periods: (a) an introductory session of the process of self-career 
DRUŠ. ISTRAŽ. ZAGREB GOD. 20 (2011) BR. $3(113)$

STR. 793-812

PINTO, J. C. TAVEIRA, M. C. SELF-CAREER.

\section{Instruments}

management; (b) four sessions of 120 minutes each, weekly, in small groups (4 to 7 participants) dedicated to the analysis of the personal career path, the development of an accurate picture of interests, values, preferred life-style, and advanced training and employment opportunities, design of short, medium and long term goals, hypotheses testing, as well as, the improvement of a strategy designed to achieve those goals; and (c) a session of consolidation and conclusion of the seminar. The evaluative measures were applied immediately before and after the psychological intervention, according to a quasi-experimental design.

The control group filled out the same questionnaires, in moments of time corresponding to the pre and post sessions of the experimental group. In both groups, we requested the participants' cooperation and willingness for the accomplishment of the instruments, explaining to them their relevance for determining the success of the seminar and to guarantee the quality of the service provided. The need to be honest in their answers and the confidentiality of the collected data were also highlighted. The completion of both questionnaires, in both groups, took approximately 45 minutes.

Career concerns were assessed through a version adapted for the Portuguese population of the Adult Career Concerns Inventory (ACCI; Super et al., 1985; IPC, adapt. by Duarte, 1997). ACCI is a self-administered scale, focused on the phases and sub-phases of Super's theoretical model of vocational development (Super et al., 1985, 13; Super, 1990). In particular, it assesses exploration (crystallization, specification, implementation), establishment (stabilizing, consolidating, advancing), maintenance (holding, updating, innovating), and disengagement (deceleration, retirement planning, retirement living). It is comprised of 61 statements reflecting career concerns at these stages, 60 using a Likert-type response format, ranging from 1 ("little concern") to 5 ("great concern"). The 61st item is constituted of five statements which represent various stages of career change. The participant chooses the statement that best describes his/her current status. In a study developed by Duarte (1993), with Portuguese workers from an industrial company $(n=979)$, the internal consistency of the measure, obtained by Cronbach's alpha, was estimated between 0.92 and 0.97 for the scales and, between 0.79 and 0.96 for the subscales.

Career exploration process was assessed through a version of the Career Exploration Survey (CES; Stumpf et al., 1983; EEV, adapt. by Taveira, 1997) adapted for Portugal. CES is a self-administered scale designed to evaluate twelve of the ori- 
DRUŠ. ISTRAŽ. ZAGREB GOD. 20 (2011), BR. 3 (113)

STR. 793-812

PINTO, J. C TAVEIRA, M. C. SELF-CAREER.

\section{Data Analysis}

\section{RESULTS}

1 The variable main research area was recoded into a dummy variable, organizing the main research areas into two distinct groups: human and social sciences, and exact science and engineering. ginal sixteen scale dimensions: five beliefs about exploration (employment outlook, certainty of career exploration outcomes, external search instrumentality, internal search instrumentality and importance of preferred position), four behaviours of the exploration process (extent of environment exploration, extent of self-exploration, intended-systematic exploration, amount of acquired information), and three reactions to exploration (satisfaction with information, exploration stress and decision stress). It is composed of 54 items, 53 using a Likert-type response format, with five response categories in items 1 to 43 , and seven response categories in items 44 to 53 (in which 1 means "little" and 5 or 7 means "a great deal"). The 54th item, using an open response format, allows individuals to specify the number of explored vocational domains. In a study developed by Taveira (1997), with Portuguese adolescents attending the 9th grade $(\mathrm{n}=700)$, CES has proved to be a psychometric robust instrument, with Cronbach alpha values ranging from 0.63 to 0.86 .

Descriptive statistics were used to characterize participants' socio-demographic condition. Simple linear regression analyses were performed $(n=24)$ with the whole sample, to determine if the demographic variables sex, change in position, and main research area ${ }^{1}$ were significantly related to each of the career dimensions. Analyses of differences between experimental and control groups at pre-test were also performed. Prior to the analysis, the variables' normality distribution was examined. Results were encouraging of the use of parametric tests. Therefore, an Independent-Samples T-Test was performed. Differences intra-group, between pre- and post-treatment were also analysed, through the application of a Paired-Samples T-Test.

GLM Univariate analyses were also executed to distinguish among experimental and control groups, at post-test, having as covariate the pre-test results.

Table 2 displays the correlations between the career exploration and career concerns variables. Employment outlook can be explained by anticipation of a change in position $\mathrm{F}(3,76)=3.833$, $\mathrm{p}<0.05 ; \mathrm{R}^{2}=0.131$ ( $\mathrm{R}^{2}$ adjusted $=0.097$ ). This relation is positive: beta $=0.281, t=2.532, p<0.05$, suggesting that employment outlook is associated with the anticipation of a change in position during the next year.

Certainty of exploration outcomes is explained by sex: $\mathrm{F}(3,76)=2.925, \mathrm{p}<0.05 ; \mathrm{R}^{2}=0.103$ ( $\mathrm{R}^{2}$ adjusted $\left.=0.068\right)$. This re- 
lationship is negative: beta $=-0.268, \mathrm{t}=-2.26, \mathrm{p}<0.05$, indicating that higher levels of certainty of exploration outcomes are associated to men.

\begin{tabular}{lllllll}
\hline Measures & Subscales & Variables & $\mathrm{r}^{2}\left(\mathrm{r}^{2}\right.$ adjusted $)$ & $\mathrm{F}(4,75)$ & Beta & $\mathrm{T}$ \\
\hline CES & $\begin{array}{l}\text { Employment outlook } \\
\text { Certainty of } \\
\text { exploration outcomes }\end{array}$ & Change in position & $0.131(0.097)$ & $3.833^{*}$ & 0.281 & $2.532^{*}$ \\
& $\begin{array}{l}\text { Amount of } \\
\text { acquired information } \\
\text { Satisfaction }\end{array}$ & Main research area & $0.315(0.288)$ & $11.635^{* * *}$ & 0.567 & $5.283^{* * *}$ \\
& $\begin{array}{l}\text { with information } \\
\text { Decision stress }\end{array}$ & Main research area & $0.181(0.149)$ & $5.607^{* *}$ & 0.365 & $3.031^{* *}$ \\
ACCI & Main research area & $0.199(0.167)$ & $6.289^{* * *}$ & -0.500 & $-4.311^{* * *}$ \\
& $\begin{array}{l}\text { Crystallization } \\
\text { Updating }\end{array}$ & Main research area & $0.204(0.173)$ & $6.508^{* * *}$ & -0.462 & $-3.955^{* * *}$ \\
& Change in position & $0.113(0.078)$ & $3.215^{*}$ & 0.323 & $2.883^{* *}$ \\
& Innovating & Main research area & $0.107(0.072)$ & $3.043^{*}$ & -0.271 & $-2.216^{*}$ \\
& & Change in position & & & 0.265 & $2.357^{*}$ \\
\hline
\end{tabular}

${ }^{*} \mathrm{p}<0.05 ;{ }^{* *} \mathrm{p}<0.01 ;{ }^{* * *} \mathrm{p}<0.001$.

(1) TABLE 2

Regression analysis: statistically significant relations between career exploration and career concerns dimensions and socio-demographic variables $(\mathrm{n}=80)$
Amount of acquired information, satisfaction with information, and decision stress are explained by the main research area: $\mathrm{F}(3,76)=11.635, \mathrm{p}<0.001 ; \mathrm{R}^{2}=0.315$ ( $\mathrm{R}^{2}$ adjusted $=0.288$ ); $\mathrm{F}(3,76)=6.289, \mathrm{p}<0.001 ; \mathrm{R}^{2}=0.199$ ( $\mathrm{R}^{2}$ adjusted $=0.167$ ); and $F(3,76)=6.289, p<0.01 ; R^{2}=0.199$ ( $R^{2}$ adjusted $=0.167$ ), respectively. This relationship is positive in the case of amount of information: beta $=0.567, t=5.283, p<0.001$, indicating that higher levels of information are associated with human and social sciences research grant-holders. In the second case, of satisfaction with information, the relationship is negative: beta $=-0.500$, $\mathrm{t}=-4.311, \mathrm{p}<0.001$, indicating that higher levels of information are associated with exact science and engineering research area. The relationship is also negative in the case of decisional stress: beta $=-.500, \mathrm{t}=-4.311, \mathrm{p}<0.001$, indicating that higher levels of stress with the decision making process are associated with the exact science and engineering research area.

In the case of ACCI, career crystallization and innovating intentions are explained by main research area: $\mathrm{F}(3,76)=6.508$, $\mathrm{p}<0.001, \mathrm{R}^{2}=0.204$ ( $\mathrm{R}^{2}$ adjusted $=0.173$ ); and, $\mathrm{F}(3,76)=3.043$, $\mathrm{p}<0.05, \mathrm{R}^{2}=0.107$ ( $\mathrm{R}^{2}$ adjusted $=0.072$ ), respectively. The relationship is negative in both cases: beta $=-0.462, t=-3.955, p<0.001$, and beta $=-0.271, \mathrm{t}=-2.216, \mathrm{p}<0.05$, indicating that lower intentions of career crystallization and of career innovation are associated with exact science and engineering research area. Moreover, intentions of updating and of innovating are explained by the anticipation of a change in position: $\mathrm{F}(3,76)=3.215$, $\mathrm{p}<0.05, \mathrm{R}^{2}=0.113$ ( $\mathrm{R}^{2}$ adjusted $=0.078$ ); and, $\mathrm{F}(3,76)=3.043, \mathrm{p}<0.05$, 
DRUŠ. ISTRAŽ. ZAGREB GOD. 20 (2011), BR. $3(113)$

STR. 793-812

PINTO, J. C., TAVEIRA, M. C. SELF-CAREER.
$R^{2}=0.107$ ( $R^{2}$ adjusted $\left.=0.072\right)$, respectively. The relationship is positive in both cases: beta $=0.323, \mathrm{t}=2.883, \mathrm{p}<0.01$, and beta $=0.265, t=2.357, p<0.05$, indicating that higher intentions of career updating and of career innovating are associated with the anticipation of a change in position during the next year.

Table 3 presents the results of descriptive statistics of career exploration and career concerns measures, and also the results of the Independent-Samples T-Test for the pre-treatment moments of both control and intervention groups.




DRUŠ. ISTRAŽ. ZAGREB GOD. 20 (2011),

BR. $3(113)$

STR. 793-812

PINTO, J. C.,

TAVEIRA, M. C

SELF-CAREER.
The results of the descriptive statistics prove that, at the pre-test, the experimental group achieved results above the mean score in six sub-scales of career exploration, namely internal search instrumentality, external search instrumentality, importance of preferred position, self-exploration, amount of acquired information, and satisfaction with information. In regard to the post-treatment results, the experimental group registered results above the mean score also in the employment outlook subscale. The results of the post-test are greater than the pre-test for all subscales of CES, with the greatest differences registered for internal search instrumentality, self-exploration, and exploration stress subscales. In respect to the career concerns measure, for the pre-test of the experimental group, we ascertain results above the mean score in all the subscales, but for the disengagement scale. With regard to the post-test scores, the same patterns of results were observed for all the subscales. The results of the post-test are inferior to the pre-test for all subscales of ACCI, except for retirement planning, with the greatest difference in the innovating, and specification subscales.

Concerning the pre-test results of the control group, results exceed the mean point in six subscales of CES, particularly, external search instrumentality, internal search instrumentality, importance of preferred position, self-exploration, amount of acquired information, and satisfaction with information. In terms of the post-test results for this group, all the subscales mentioned before scored higher than the mean score. When compared with pre-test, the post-test results are higher in half of the CES subscales, excluding external search instrumentality, self-exploration, environment exploration, intended-systematic exploration, amount of acquired information, and satisfaction with information subscales. On the career concerns measure, for the pre-test of the control group, the results were higher than the mean point for the subscales corresponding to the establishment and maintenance phases, and also for the implementation subscale of the exploration phase. With regard to the post-test values, a similar pattern of results was registered. The post-test results are lower than the pre-test, in all subscales of the ACCI.

To assess the equivalence of these two groups at the beginning of the intervention, Independent-Samples T-Test was used. Table 4 shows that, concerning the career exploration subscales, there were no statistically significant differences between the two groups, except in the dimensions of internal search instrumentality $(\mathrm{t}(78)=2,79, \mathrm{p}=0.03)$, amount of acquired information $(\mathrm{t}(78)=3.988, \mathrm{p}=0.00)$, satisfaction with information $(\mathrm{t}(78)=-3.639, \mathrm{p}=0.00)$, and decision stress $(\mathrm{t}(78)=1.984$, $\mathrm{p}=0.02)$. Thus, when compared with the control group, the experimental group showed a greater prospect of self-explo- 
DRUŠ. ISTRAŽ. ZAGREB GOD. 20 (2011), BR. 3 (113)

STR. 793-812

PINTO, J. C. TAVEIRA, M. C. SELF-CAREER.

\section{(1) TABLE 4}

Career exploration and career concerns: statistics of the Paired-Sample T-Test and differences between experimental and control groups ration to contribute to the achievement of desired career goals, as well as, higher levels of stress in terms of the decision-making processes. In contrast, it was the control group who showed a greater amount of obtained information about the jobs, employment, and organizations connected with their interests, abilities and needs, as well as, a greater satisfaction with the acquired information. Regarding the career concerns, there were, also, no statistically significant differences between the two groups, except for the crystallization $(t(78)=3.076, p=0.00)$ and specification $(\mathrm{t}(78)=2.199, \mathrm{p}=0.03)$ subscales. This means that, when compared with the experimental group, the control group exhibits lower levels of concern about the attainment of professional recognition in the desired areas, as well as, with a consistent expression, of the previous choices in the format of a job, employment or specialization.

Therefore, these results suggest that experimental and control groups were mainly equivalent at pre-test, considering all evaluated dimensions.

\begin{tabular}{|c|c|c|c|c|c|}
\hline Measures & Scales & Subscales & $\begin{array}{l}\text { Experimental } \\
\text { Group } \\
(\mathrm{n}=50) \\
\text { Paired- } \\
\text {-Samples } \\
\text { T-Test } \\
\mathrm{t}(49)\end{array}$ & $\begin{array}{l}\text { Control } \\
\text { Group } \\
(\mathrm{n}=30) \\
\text { Paired- } \\
\text {-Samples } \\
\text { T-Test } \\
\mathrm{t}(29)\end{array}$ & $\begin{array}{l}\text { Mean Difference } \\
\text { (Experimental } \\
\text { Group-Control } \\
\text { Group) }\end{array}$ \\
\hline \multirow[t]{3}{*}{ CES } & Beliefs & $\begin{array}{l}\text { Employment Outlook } \\
\text { Certainty of Exploration Outcomes } \\
\text { External Search Instrumentality } \\
\text { Internal Search Instrumentality } \\
\text { Importance of Preferred Position }\end{array}$ & $\begin{array}{l}4.257^{* * *} \\
4.41^{* * *} \\
1.928 \\
9.387^{* * *} \\
1.577\end{array}$ & $\begin{array}{l}0.779 \\
0.166 \\
-0.129 \\
2.755^{* *} \\
2.040\end{array}$ & $\begin{array}{l}1.275^{*} \\
0.956 \\
1.299^{*} \\
3.549^{*} \\
-0.696\end{array}$ \\
\hline & Behaviors & $\begin{array}{l}\text { Self-Exploration } \\
\text { Environment Exploration } \\
\text { Intended-Systematic Exploration } \\
\text { Amount of Acquired Information }\end{array}$ & $\begin{array}{l}5.762^{* * *} \\
3.758^{* * *} \\
1.795 \\
4.344^{* * *}\end{array}$ & $\begin{array}{l}-1 \\
-1.854 \\
-0.372 \\
-0.496\end{array}$ & $\begin{array}{l}2.135^{* *} \\
5.229^{* * *} \\
0.201 \\
0.386\end{array}$ \\
\hline & Reactions & $\begin{array}{l}\text { Satisfaction with Information } \\
\text { Exploration Stress } \\
\text { Decision Stress }\end{array}$ & $\begin{array}{l}2.879^{* *} \\
3.855^{* * *} \\
0.244\end{array}$ & $\begin{array}{r}-0.549 \\
1.158 \\
0.809\end{array}$ & $\begin{array}{l}1.098 \\
1.746^{*} \\
0.418\end{array}$ \\
\hline \multirow[t]{4}{*}{ ACCI } & Exploration & $\begin{array}{l}\text { Crystallization } \\
\text { Specification } \\
\text { Implementation }\end{array}$ & $\begin{array}{l}-1.794 \\
-1.247 \\
-0.073\end{array}$ & $\begin{array}{l}-1.157 \\
-1.066 \\
-0.243\end{array}$ & $\begin{array}{l}1.017 \\
1.427 \\
0.918\end{array}$ \\
\hline & Establishment & $\begin{array}{l}\text { Stabilizing } \\
\text { Consolidating } \\
\text { Advancing }\end{array}$ & $\begin{array}{l}-0.538 \\
-0.587 \\
-0.989\end{array}$ & $\begin{array}{l}-0.054 \\
-1.208 \\
-1.206\end{array}$ & $\begin{array}{r}-0.905 \\
0.055 \\
-0.383\end{array}$ \\
\hline & Maintenance & $\begin{array}{l}\text { Holding } \\
\text { Updating } \\
\text { Innovating }\end{array}$ & $\begin{array}{l}-0.311 \\
-0.749 \\
-2.439^{*}\end{array}$ & $\begin{array}{l}-0.657 \\
-8.49 \\
0.038\end{array}$ & $\begin{array}{c}-0.44 \\
0.258 \\
-0.571\end{array}$ \\
\hline & Disengagement & $\begin{array}{l}\text { Deceleration } \\
\text { Retirement Planning } \\
\text { Retirement Living }\end{array}$ & $\begin{array}{r}-0.379 \\
1.077 \\
-0.206\end{array}$ & $\begin{array}{l}-0.047 \\
-1.266 \\
-0.342\end{array}$ & $\begin{array}{l}-0.727 \\
1.24 \\
0.257\end{array}$ \\
\hline
\end{tabular}

${ }^{*} \mathrm{p}<0.05 ;{ }^{* *} \mathrm{p}<0.01 ;{ }^{* * *} \mathrm{p}<0.001$ 
DRUŠ. ISTRAŽ. ZAGREB GOD. 20 (2011) BR. $3(113)$

STR. 793-812

PINTO, J. C. TAVEIRA, M. C. SELF-CAREER.

\section{DISCUSSION}

Table 4 shows the differences between post and pre-test measures of exploration and career concerns dimension within group, and also, the mean differences between the experimental and control groups, at post-test, having as covariate the pre-test results.

Thus, in the experimental group, the difference in the mean values was statistically significant for the employment outlook $(\mathrm{t}(49)=4.257, \mathrm{p}=0.00)$, certainty of exploration outcomes $(\mathrm{t}(49)=4.41, \mathrm{p}=0.00)$, internal search instrumentality $(\mathrm{t}(49)=9.387, \mathrm{p}=0.00)$, environment exploration $(\mathrm{t}(49)=3.758$, $\mathrm{p}=0.00$ ), self-exploration ( $\mathrm{t}(49)=5.762, \mathrm{p}=0.00)$, amount of acquired information $(\mathrm{t}(49)=4.344, \mathrm{p}=0.00)$, satisfaction with information $(\mathrm{t}(49)=2.879, \mathrm{p}=0.01)$ and exploration stress $(\mathrm{t}(49)=3.855, \mathrm{p}=0.00)$ subscales. Concerning the ACCI, a decrease is noted in all the dimensions of the instrument, although the innovating subscale $(\mathrm{t}(49)=-2.439, \mathrm{p}=0.02)$ was the only statistically significant one.

In the case of the control group, and taking into account the dimensions of CES, the results suggest a statistically significant result in the internal search instrumentality, subscale $(\mathrm{t}(29)=2.755, \mathrm{p}=0.01)$. As for the ACCI, no results have proven statistically significant.

The mean difference analysis between experimental and control groups, at post-test, having the results of the pre-test as co-variation variable, reveals statistically significant differences in the following career exploration dimensions: employment outlook $(F(1,77)=1.275, p=0.02)$, external search instrumentality $(F(1,77)=1.299, p=0.05)$, internal search instrumentality $(\mathrm{F}(1,77)=3.549, \mathrm{p}=0.01)$, self-exploration $(\mathrm{F}(1,77)=2.135$, $\mathrm{p}=0.00)$, environment exploration $(\mathrm{F}(1,77)=5.229, \mathrm{p}=0.00)$, and exploration stress $(\mathrm{F}(1,77)=1.746, \mathrm{p}=0.05)$, with better results in the experimental group. With respect to the career concern dimensions, no differences have proven to be statistically significant between those groups.

The aim of this research was to examine the results of a self-career management intervention. The study was carried out with the pre and post-test results of career exploration and career concerns of a group of research grant holders, and in comparison with a control group.

Results of this research suggest that both groups were at the same level in respect to career exploration and career concerns, at pre-test. A detailed analysis of the results allowed us to verify that prior to the career management intervention there were nearly no statistically significant differences between both groups.

With regard to the dimensions measured by CES, the only differences we found were, as stated above, in the internal search instrumentality, and decision stress subscales, in favor 
DRUŠ. ISTRAŽ. ZAGREB GOD. 20 (2011), BR. 3 (113)

STR. 793-812

PINTO, J. C. TAVEIRA, M. C. SELF-CAREER. of the experimental group, and also in the amount of acquired information, and satisfaction with information subscales, in favor of the control group. These results indicate that, at pre-test, the experimental group had a higher level of beliefs in the possibility that self-exploration (e.g., in terms of interests, values, preferred lifestyle, skills) would foster the achievement of personal career goals. This can be understood as one of the reasons that might have led these people to submit their application to attend the personal career management seminar, once the advertising revealed that the program invites participants to increase their self-knowledge, and therefore, to conceive future career goals. The experimental group also had higher levels of stress relating to the performance of decision activities related to career, and with comparison to other life events. According to the theory and research in the field of vocational exploration, moderate levels of stress, such as those found here can serve as an incentive for future exploratory activity (Taveira, 1997). Moreover, the results for the control group suggest that, at the pre-test, the subjects were quite satisfied with the amount of information they had about themselves and about the professional world (professions, jobs, organizations), and were also very satisfied with the quality of that information. These results may help us understand some of the reasons that may be behind the choice of not signing up for this seminar. Possibly, the subjects of this group believed that they did not need to increase their self-knowledge, or became more aware of the advanced training employment creation and attainment opportunities.

In the case of the ACCI dimensions, there were only statistically significant differences in the crystallization and the specification subscales, in favor of the control group. This means that, compared with the experimental group, the control group was, at pre-test, less concerned about the exploration and recognition of the desired professional fields and levels, and with the consistent expression of that professional choice.

It is noteworthy that these results are consistent with those obtained in the regression analysis. The experimental group is composed of more research grant holders from the exact science and engineering area, in comparison with the control group, and obtained better results in the decision stress subscale. In contrast, the control group, consisting of research grant holders from the human and social sciences area, was more satisfied with both the quantity and the quality of career information.

Concerning the effectiveness of the career intervention, the results also show that, in terms of intra-group comparison, the experimental group obtained both positive and statistically significant changes in all three dimensions of CES - beliefs, 
DRUŠ. ISTRAŽ. ZAGREB GOD. 20 (2011) BR. $3(113)$

STR. 793-812

PINTO, J. C., TAVEIRA, M. C. SELF-CAREER.

\section{Limitations}

behaviors, and reactions to the career exploration. Specifically, the group reported, after the intervention, higher beliefs about the possibility of obtaining employment in the preferred area, of obtaining a favorable position in the labor market, as well as, about the possibility of the self-information contribution to the achievement of career goals. Also, it had a greater involvement in career exploration behaviors, in particular, higher levels of personal information, and about employers, jobs and organizations, which resulted in a greater amount of information. There were also increases in reactions to career exploration, particularly in terms of increasing levels of satisfaction with the information obtained and the amount of stress related to the exploration process. As for the ACCI, only the innovating subscale showed statistically significant results. This subscale refers to a concern and need on the part of individuals to explore different activities and do them in a different way.

In contrast, the comparison of results of pre and posttest, referring to the control group, explains the existence of only a statistically significant change in the internal search instrumentality subscale. Thus, the subjects of the control group seem to have been, in those five weeks, involved in some kind of activity that allowed them to increase self-information, and thus to become more confident in relation to the achievement of their career goals. It would be important to return to that group and seek to clarify the reasons that may be behind this result.

The mean differences between the experimental and the control groups, at post-test, having the results of the pre-test moment as co-variation variable, confirmed that the experimental group registered more favorable career exploration results, after the intervention.

Overall, this study suggests that this intervention in self-career management, offered to research grant holders, was effective in promoting career exploration beliefs, behaviors, and reactions. In this sense, we consider this to be a useful intervention that promotes positive effects in its clients, but it would be important to pursue this line of research in order to explain why it had almost any effect in decreasing the level of career concerns.

This study has some sampling and methodological limitations that may affect the generalizability of the findings. One issue concerns the composition of the sample. The experimental group consisted of students who had knowledge of the program, and within these, those who felt the need to work on 
DRUŠ. ISTRAŽ. ZAGREB GOD. 20 (2011), BR. $3(113)$

STR. $793-812$

PINTO, J. C., TAVEIRA, M. C. SELF-CAREER. their self-career management skills. Moreover, the sample consisted only of students from one university institution.

Therefore, the results obtained here cannot be generalized to the entire population of research grant holders. Another important issue concerns the type and application moment of the instruments. The use of self-report instruments has limited our findings to the respondents' perceptions, which may have been affected by social desirability.

The use of the ACCI can be quite relevant in helping us understand the career development stages, in which individuals find themselves, as well as, career needs and concerns associated with them, however, it seems to have some difficulty in differentiating subjects before and after the intervention, in the assessed career dimensions. Unfortunately, given the shortage of properly validated instruments to the Portuguese population, this instrument was presented as the most appropriate, given the goals of the intervention program.

Furthermore, the use of a pre- and post-test methodology does not allow us to verify that program results remain over time. Future studies could benefit through the introduction of a more equal sample, in terms of experimental and control groups, as well as through the addition of multiple methodologies and a follow-up.

\section{Implications for Practice}

This study has some practical implications, particularly with regard to human resources management. The theoretical review presented in the first part of this article stresses that the rapid changes that are occurring in the world organization are reflected in the way, either the organizations, or individuals, deal with policies and practices of career management (Sturges et al., 2008). Taking into account the existing constraints of the world of work, it is not expected that people leave their own professional development management in charge of educational or work organizations (Amundson, 2006). If in the past these organizations were the only ones responsible for managing the career of each employee, now this situation would be unacceptable. For this reason, the focus of the responsibility for managing careers has been gradually transferred from the organization to the individual (e.g., Appelbaum et al., 2002; Murphy and Ensher, 2001; Orpen, 1994). This does not mean, however, that organizations should be completely out of this task. Whether those individuals are, or not, experiencing a career change, organizations, and particularly human resource managers, must also take an active role in helping their employees. 
DRUŠ. ISTRAŽ. ZAGREB GOD. 20 (2011)

BR. $3(113)$

STR. 793-812

PINTO, J. C., TAVEIRA, M. C. SELF-CAREER.

\section{REFERENCES}

It is the responsibility of the organizations to hire career professionals able to carry out the tasks of career management that best suit the individuality of each employee. Only with a full knowledge of their needs and resources, it will be possible to develop and involve workers in career management programs. These programs should be constituted by a set of activities that allow each worker to construct and express his own self. Through this process, all people can build a new career history, in which they become "who they are and live the lives they have imagined" (Savickas, 2005, 68). Moreover, it is equally important that organizations increase their understanding of the implications of such career management activities and programs, namely, that they evaluate its impact on employee's attitudes and behaviors. In most cases, the involvement in the career management activities is associated with greater organizational effectiveness, and also with higher levels of employee satisfaction (cf. Uhl-Bien and Graen, 1998; Orpen 1994). However, we cannot forget that individuals will only enroll themselves in such activities if they perceive them as genuinely interested in their career problems.

With this work we intend to strengthen the notion of shared responsibility by the aggregate of obligations that underpin the career management process. The assumption of this joint responsibility will be the most effective way to ensure that the process of career management is meeting both the individual career needs and the workforce organizations demands (Leibowitz et al., 1986).

Amundson, N. (2006), Challenges for Career Interventions in Changing Contexts. International Journal for Educational and Vocational Guidance, 6 (1): 3-14. doi:10.1007/s10775-006-0002-4

Appelbaum, S. H., Ayre, H. \& Shapiro, B. T. (2002), Career Management in Information Technology: A Case Study. Career Development International, 7 (3): 142-158.

Arthur, M. B. \& Rousseau, D. M. (1996), The Boundaryless Career: A New Employment Principle for a New Organizational Era, New York, Oxford University Press.

Arthur, M. B., Claman, P. H. \& DeFillipi, R. J. (1995), Intelligent Enterprise, Intelligent Careers. Academy of Management Executive, 9 (4): 7-22. doi:10.5465/AME.1995.9512032185

Athanasou, J. A. \& Esbroeck, R. (2008), International Handbook of Career Guidance, Netherlands, Springer. doi:10.1007/978-1-4020-6230-8

Chen, C. P. (1997), Career Projection: Narrative in Context. Journal of Vocational Education and Training, 49 (2): 311-326. doi:10.1080/13636 829700200012

DeFillipi, R. J. \& Arthur, M. B. (1994), The Boundaryless Career: A Competency-Based Prospective. Journal of Organizational Behavior, 15 (4): 307-324. 
DRUŠ. ISTRAŽ. ZAGREB GOD. 20 (2011), BR. $3(113)$

STR. 793-812

PINTO, J. C TAVEIRA, M. C. SELF-CAREER...
Duarte, M. E. (1993), Preocupações de carreira, valores e saliência das actividades em adultos empregados [Career Concerns, Values, and Salience, in the Activities of Adult Workers]. Unpublished doctoral dissertation, Faculty of Psychology and Education Sciences, Portugal.

Duarte, M. E. (1997), A avaliação em orientação e desenvolvimento da carreira [Assessment in career development and guidance]. In: M. Gonçalves, I. Ribeiro, S. Araújo, C. Machado, L. Almeida \& M. Simões (Eds.), Avaliação psicológica: formas e contextos (pp. 385-391), Braga, Associação Portuguesa de Psicologia (APPORT).

Faria, L. \& Taveira, M. C. (2006, November), Avaliação dos resultados da intervenção psicológica vocacional: um estudo de avaliação de resultados em

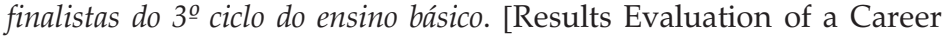
Intervention: A Study to Evaluate the Results of 9th Grade Students]. Paper presented at the meeting VI National Symposium in Psychology Investigation, Évora, Portugal.

Frayne, C. A. \& Geringer, J. M. (2000), Self-Management Training for Improving Job Performance: A Field Experiment Involving Salespeople. Journal of Applied Psychology, 85 (3): 361-372. doi:10.1037// 0021-9010.85.3.361

Fretz, B. R. (1981), Evaluating the Effectiveness of Career Interventions. Journal of Counseling Psychology, 28 (1): 77-90. doi:10.1037//00220167.28.1.77

Greenhaus, J. H. \& Callanan, G. A. (1994), Career Management (2nd ed.), Fort Worth, TX: Dryden Press.

Hall, D. T. (1996), Introduction: Long Live the Career - A Relational Approach. In: D. T. Hall (Ed.), The Career Is Dead - Long Live the Career: A Relational Approach to Careers (pp. 1-12), San Francisco, Jossey-Bass Publishers.

Hall, D. T. \& Moss, J. E. (1998), The New Protean Career Contract: Helping Organizations and Employees Adapt. Organizational Dynamics, 26 (3): 22-37. doi:10.1016/S0090-2616(98)90012-2

Handy, C. (1994), The Age of Paradox, Boston, Harvard Business School Press.

Holland, J. C., Maggon, T. M. \& Spokane, A. R. (1981), Counseling Psychology: Career Interventions, Research and Theory. Annual Review of Psychology, 32: 279-315. doi:10.1146/annurev.ps.32.020181. 001431

King, Z. (2004), Career Self-Management: Its Nature, Causes and Consequences. Journal of Vocational Behavior, 65 (1): 112-133. doi:10. 1016/ S0001-8791(03)00052-6

Kossek, E., Roberts, K., Fisher, S. \& Demarr, B. (1998), Career Self-Management: A Quasi Experimental Assessment of the Effect of a Training Intervention. Personnel Psychology, 51 (4): 935-960. doi:10.1111/ j.1744-6570.1998.tb00746.x

Leibowitz, Z. B., Farren, C. \& Kaye, B. L. (1986), Designing Career Development Systems, San Francisco, Jossey-Bass Publishers.

Luzzo, D. A. (2000), Career Counseling of College Students: An Empirical Guide to Strategies That Work, Washington DC, American Psychological Association. doi:10.1037/10362-000 
DRUŠ. ISTRAŽ. ZAGREB GOD. 20 (2011) BR. 3 (113),

STR. 793-812

PINTO, J. C., TAVEIRA, M. C SELF-CAREER.
McIlveen, P. \& Patton, W. (2007), Narrative Career Counselling: Theory and Exemplars of Practice. Australian Psychologist, 42 (3): 226-235. doi:10.1080/00050060701405592

Murphy, S. E. \& Ensher, E. A. (2001), The Role of Mentoring Support and Self-Management Strategies on Reported Career Outcomes. Journal of Career Development, 27 (4): 229-246. doi:10.1023/A:1007866919494

Noe, R. A. (1996), Is Career Management Related to Employee Development and Performance? Journal of Organizational Behavior, 17 (2): 119-133. doi:10.1002/(SICI)1099-1379(199603)17:2<119:AID-JOB 736>3.3.CO;2-F

Orpen, C. (1994), The Effects of Organizational and Individual Career Management on Career Success. International Journal of Manpower, 15 (1): 27-37.

Rounds, J. B. \& Tinsley, H. E. A. (1984), Diagnosis and Treatment of Vocational Problems. In: S. D. Brown \& R. W. Lent (Eds.), Handbook of Counseling Psychology (pp. 137-177), New York, John Wiley \& Sons.

Savickas, M. (2005), The Theory and Practice of Career Construction. In: S. D. Brown \& R. W. Lent, Career Development and Counseling (pp. 42-70), New Jersey, John Wiley \& Sons.

Savickas, M. (2008), Helping People Choose Jobs: A History of the Guidance Profession. In: J. A. Athanasou \& R. Esbroeck (Eds.), International Handbook of Career Guidance (pp. 97-113), Netherlands, Springer.

Silva, A. D. (2008), A construção de carreira no ensino superior [Career Construction in Higher Education]. Unpublished doctoral dissertation, University of Minho, Portugal.

Soares, A. P. (1998), Desenvolvimento vocacional de jovens e adultos: A exploração, a indecisão e o ajustamento vocacional em estudantes universitários [Young and Adults Vocational Development: Career Exploration, Career Indecision, and Academic Adjustment in University Students]. Unpublished master dissertation, University of Minho, Portugal.

Stumpf, S. A., Colarelli, M. S. \& Hartman, K. (1983), Development of the Career Exploration Survey (CES). Journal of Vocational Behavior, 22 (2): 191-226. doi:10.1016/0001-8791(83)90028-3

Sturges, J., Conway, N. \& Liefooghe, A. (2008), What's the Deal? An Exploration of Career Management Behaviour in Iceland. The International Journal of Human Resource Management, 19 (4): 752-768. doi:10. 1080/09585190801953814

Super, D. (1990), A Life-Span, Life-Space Approach to Career Development. In: D. Brown \& L. Brooks (Eds.), Career Choice and Development (pp. 197-261), San Francisco, Jossey-Bass Publishers.

Super, D., Thompson, A. S. \& Lindeman, R. H. (1985), Adult Career Concerns Inventory: Manual for Research and Exploratory Use in Counseling, Palo Alto, CA, Consulting Psychologists Press.

Swanson, J. L. (1995), The Process and Outcome of Career Counseling. In: W. B. Walsh \& S. H. Osipow (Eds.), Handbook of Vocational Psychology: Theory, Research and Practice (pp. 217-259), New York, Lawrence Erlbaum Associates, Inc.

Taveira, M. C. (1997), Exploração e desenvolvimento vocacional de jovens: estudo sobre as relações entre a exploração, a identidade e a indecisão voca- 
DRUŠ. ISTRAŽ. ZAGREB GOD. 20 (2011), BR. 3 (113)

STR. $793-812$

PINTO, J. C TAVEIRA, M. C. SELF-CAREER.. cional [Exploration and Vocational Development of Youth: A Study on the Relationship between Career Exploration, Indecision and Identity]. Published doctoral dissertation, University of Minho, Portugal. Taveira, M. C., Silva, A. D., Loureiro, M. N., Araújo, A., Faria, L., Pinto, J. C. \& Sousa, S. (2007), Seminário de Gestão Pessoal da Carreira versão $A, B, e$ C. [Self-Career Management Seminar - Version A, B, and C.] Unpublished manuscript, University of Minho, Portugal.

Uhl-Bien, M. \& Graen, G. B. (1998), Individual Self-Management: Analysis of Professionals' Self Managing Activities in Functional and Cross-Functional Work Teams. Academy of Management Journal, 41 (3): 340-350. doi:10.2307/256912

Van Vianen, A. E. M., De Pater, I. E. \& Preenen, P. T. Y. (2008), Career Management: Taking Control of the Quality of Work Experiences. In: J. A. Athanasou \& R. Esbroeck (Eds.), International Handbook of Career Guidance (pp. 283-301), Netherlands, Springer.

Whiston, S. C. \& Buck, I. M. (2008), Evaluation of Career Guidance Programs. In: J. A. Athanasou \& R. Esbroeck (Eds.), International Handbook of Career Guidance (pp. 677-692), Netherlands, Springer.

\section{Samoupravljanje karijerom: intervencija s nositeljima istraživačkih stipendija}

Joana Carneiro PINTO, Maria do Céu TAVEIRA

Psihologiijski istraživački centar, Sveučilište Minho, Braga, Portugal

Ovaj članak izvještava o rezultatima procjene učinkovitosti intervencije za unapređenje samoupravljanja karijerom, pod nazivom "Seminar o samoupravljanju karijerom". Intervencija je posebno razvijena i primijenjena unutar skupine nositelja istraživačkih stipendija. Program poziva sudionike da unapređuju vlastito znanje, znanje o novim, boljim, mogućnostima usavršavanja, o otvaranju radnih mjesta i radnim dostignućima, kao i da pobolišaju vještine planiranja života i karijere te sposobnost donošenja odluka. Interveniralo se kod 80 nositelja stipendija (50, 62,5\% eksperimentalna skupina; 30, 37,5\% kontrolna skupina; 51 , 63,8\% žene; Mdob $=28,94$, SDdob $=5,83)$, na javnom sveučilištu na sjeverozapadu Portugala. Stipendisti su podvrgnuti mjerenju karijernog usmjeravanja i zabrinutosti tijekom predtestiranja i posttestiranja. Rezultati su pokazali izjednačenost između eksperimentalne i kontrolne skupine, u predtestiranju, u gotovo svim ispitanim dimenzijama. Nadalje, u usporedbi s kontrolnom skupinom, nositelii istraživačkih stipendija koji su prisustvovali intervenciji ostvarili su u post-testu više razine razvoja karijere. Ova studija naglašava potrebu za razvojem intervencijskih programa prilagođenih specifičnim populaciijskim skupinama, kao što su istraživački stipendisti.

Ključne riječi: samoupravljanje karijerom, intervencija, učinkovitost 
DRUŠ. ISTRAŽ. ZAGREB

GOD. 20 (2011)

BR. $3(113)$

STR. 793-812

PINTO, J. C.

TAVEIRA, M. C.

SELF-CAREER.

\section{Karrieremanagement: Eine Untersuchung mit Forschungsstipendiaten}

Joana Carneiro PINTO, Maria do Céu TAVEIRA

Psychologisches Forschungszentrum,

Universität Minho, Braga, Portugal

Dieser Artikel präsentiert die Ergebnisse einer Untersuchung, innerhalb deren ein eigens für Forschungsstipendiaten entwickeltes Seminar für Karrieremenagement angeboten wurde. Die Seminarteilnehmer waren dazu angehalten, ihre Kenntnisse über verbesserte Edukations- und

Beschäftigungsmöglichkeiten sowie Arbeitsleistungen zu vermehren; ebenso sollten sie lernen, ihre Lebens- und Karriereplanung zu verbessern und das Fällen von Entscheidungen zu optimieren. An dem Seminar, das an einer staatlichen Universität im Nordwesten Portugals abgehalten wurde, nahmen 80 Stipendiaten teil: 50 Teilnehmer $(62,5 \%)$ bildeten die Experimentalgruppe, die übrigen 30 Teilnehmer $(37,5 \%)$ stellten die Kontrollgruppe dar; unter den Teilnehmern befanden sich 51 Frauen $(63,8 \%) ;$ MAlter $=28,94$, SDAlter $=5,83)$. Die Untersuchungsleiter ermittelten die karrieremäßige Ausrichtung der Probanden sowie ihre während eines Vorund eines Nachtests geäußerte Besorgnis. Gemäß den Untersuchungsergebnissen gibt es keine Unterschiede zwischen der Experimental- und der Kontrollgruppe hinsichtlich nahezu aller im Vortest geprüften Dimensionen. Des Weiteren ist ersichtlich, dass die Forschungsstipendiaten, die am Seminar teilnahmen, im Unterschied zu den Mitgliedern der Kontrollgruppe, im Nachtest besser abschnitten und ein besseres Karrieremanagement an den Tag zu legen wussten. Mit dieser Untersuchung soll hervorgehoben werden, dass interventionsmäßige Seminarangebote für spezifische Bevölkerungsgruppen, so etwa die hier angesprochenen Forschungsstipendiaten, notwendig sind und gezielt entwickelt werden müssen.

Schlüsselbegriffe: Karrieremangement, Hilfsangebote, Leistungsstärke 